Volume 10, Nomor 1, Mei 2018, pp 98-116 Copyright @) 2017 Jurnal Akuntansi Maranatha, Program Studi Akuntansi, Fakultas Ekonomi, Universitas Kristen Maranatha. ISSN 2085-8698 | e-ISSN 2598-4977. http://journal.maranatha.edu

\title{
Pengaruh Kinerja Keuangan dan Tata Kelola Perusahaan Terhadap Nilai Perusahaan pada Industri Telekomunikasi di Bursa Efek Indonesia
}

\author{
Monica Paramita Ratna Putri Dewanti \\ Fakultas Ekonomi-Univ. Katolik Parahyangan \\ monica.paramita@unpar.ac.id \\ Hamfri Djajadikerta \\ Fakultas Ekonomi-Univ. Katolik Parahyangan
}

\begin{abstract}
Investor as a principal want to maximize whealth and prosperity by increasing firm value. Firm value for companies listed as issuer in Indonesia Stock Exchange can be reflected through share price. Firm value can be affected by several factors, such as financial performance and corporate governance. This research aimed to examine the influence of financial performance and corporate governance to firm value in sub-sector telecomunication industry which listed in Indonesia Stock Exchange during 2011 to 2016. The dependent variable is firm value. Meanwhile the independent variables are (1) financial performance which measured by current ratio, receivable turnover, debt to equity ratio, return on assets, and earnings per share and (2) corporate governance which measured by percentage of institutional ownership, percentage of independent board of commissioners, and presence of the audit committee. The result showed that current ratio, receivable turnover, debt to equity ratio, earning per share, and presence of the audit committee partially had no significant influence to firm value. Meanwhile return on assets, percentage of institutional ownership, and percentage of independent board of commissioners partially had significant influence to firm value. Simultaneously current ratio, receivable turnover, debt to equity ratio, return on assets, earnings per share, percentage of institutional ownership, percentage of independent board of commissioners, and presence of the audit committee had significant influence to fim value.
\end{abstract}

Keywords: Financial Performance, Corporate Governance, and Firm Value

\section{Pendahuluan}

Pemegang saham merupakan individu atau institusi yang menginvestasikan dananya dalam perusahaan melalui mekanisme pembelian saham yang beredar baik untuk investasi jangka panjang maupun jangka pendek. Pemegang saham dengan investasi jangka panjang bertujuan memperoleh pendapatan dari dividen yang dibagikan. 
Kesejahteraan pemegang saham tersebut menjadi tujuan utama perusahaan yang tidak terlepas dari upaya untuk meningkatkan nilai perusahaan. Meningkatnya nilai perusahaan dalam jangka panjang menjamin keberlangsungan perusahaan di masa yang akan datang sekaligus memastikan tersedianya dividen untuk para pemegang saham di masa yang akan datang.

Nilai perusahaan untuk perusahaan yang terdaftar di BEI dapat tercermin melalui harga saham yang beredar, di mana semakin tinggi harga saham maka semakin tinggi nilai perusahaan tersebut di mata para pemegang saham dan calon investor. Menurut Repi, Murni, dan Adare (2016) nilai perusahaan adalah harga saham yang bersedia dibayar oleh investor untuk setiap lembar saham perusahaan, sehingga dapat dikatakan bahwa nilai perusahaan merupakan persepsi investor terhadap perusahaan yang selalu dikaitkan dengan harga saham. Sementara Tjandrakirana dan Monika (2014) berpendapat bahwa nilai perusahaan juga menunjukkan pandangan para investor akan prestasi perusahaan dalam mengelola sumber dayanya.

Perubahan harga saham bergantung terhadap penilaian investor mengenai kinerja perusahaan. Pengukuran kinerja perusahaan ini biasa dilakukan dengan menggunakan rasio-rasio keuangan. Analisis rasio keuangan yang umum digunakan ialah rasio likuiditas, rasio aktivitas, rasio utang, rasio profitabilitas, dan rasio pasar. Rasio keuangan yang baik memberikan sinyal kinerja perusahaan yang baik sehingga cenderung mengundang investor untuk berinvestasi serta mendorong kenaikan harga saham yang mencerminkan peningkatan nilai perusahaan.

Selain mempertimbangkan faktor finansial perusahaan, kerap kali investor juga memperhatikan aspek non finansial di dalam perusahaan sebelum memutuskan untuk berinvestasi. Salah satunya dengan melihat tata kelola perusahaan. Tata kelola perusahaan menurut Siagian, Siregar, dan
Rahadian (2013) memungkinkan adanya pengawasan dan kontrol sehingga manajemen dalam membuat keputusan selalu mementingkan kepentingan para pemegang saham. Tata kelola perusahaan menurut mereka juga meningkatkan perlindungan kepada para pemegang saham terhadap kemungkinan perilaku oportunis manajemen yang dapat menurunkan nilai perusahaan.

Penelitian terdahulu Durnev dan Kim dalam Siagian, Siregar, dan Rahadian (2013) menemukan bahwa perusahaan dengan ranking tata kelola dan transparansi yang baik dinilai lebih tinggi dalam pasar. Tata kelola yang baik cenderung memberikan nilai lebih berupa jaminan kepada para investor bahwa investasi mereka akan dilindungi dan kesejahteraan pemegang saham tetap menjadi tujuan dari perusahaan, siapapun manajemennya. Nilai lebih ini memberikan daya tarik tambahan bagi investor sehingga menimbulkan keinginan berinvestasi dan mendorong kenaikan harga saham yang mencerminkan nilai perusahaan.

\section{Kerangka Teoritis dan Hipotesis}

\section{Nilai Perusahaan}

Tujuan utama perusahaan adalah memaksimumkan kekayaan para pemegang saham. Menurut Nurlela dan Islahudin dalam Suhartanti dan Asyik (2015), nilai perusahaan didefinisikan sebagai nilai pasar. Dituturkan lebih lanjut bahwa nilai perusahaan dapat memberikan kemakmuran bagi pemegang saham. Brigham dan Gapensky dalam Anggitasari dan Mutmainah (2012) menyatakan bahwa nilai perusahaan yang tinggi akan diikuti oleh kemakmuran pemegang saham.

Menurut Fama dalam Anggitasari dan Mutmainah (2012), nilai perusahaan akan tercermin dari harga sahamnya. Nilai perusahaan yang dibentuk dengan indikator nilai pasar saham sangat dipengaruhi oleh 
peluang investasi. Peluang investasi memberikan sinyal postif tentang pertumbuhan perusahaan di masa yang akan datang, sehingga dapat meningkatkan harga saham. Dengan meningkatnya harga saham maka nilai perusahaan pun akan meningkat.

\section{Kinerja Keuangan}

Tjandrakirana dan Monika (2014) mendefinisikan kinerja sebagai pencapaian perusahaan dalam memenuhi target perusahaan sepanjang waktu tertentu yang menggambarkan kualitas perusahaan. Kinerja perusahaan terkait keuangan dapat tercermin dalam laporan keuangan perusahaan. Menurut Jumingan dalam Tjandrakirana dan Monika (2014), laporan keuangan disusun dan ditafsirkan untuk kepentingan manajemen dan pihak lain yang menaruh perhatian atau mempunyai kepentingan dengan data keuangan perusahaan. Untuk menilai kinerja keuangan, investor dapat menggunakan analisis rasio keuangan. Ross, Westerfield, dan Jaffe (2010), menyebutkan beberapa rasio tradisional yang umum digunakan, yaitu:

1. Rasio Likuiditas

Rasio likuiditas digunakan untuk menyediakan informasi mengenai likuiditas perusahaan, yaitu kemampuan perusahaan membayar hutang jangka pendek tanpa kesulitan. Salah satu cara untuk mengukur likuiditas ialah dengan menggunakan Current Ratio yang dirumuskan sebagai berikut:

$$
\text { Current ratio }=\frac{\text { Current assets }}{\text { Current liabilities }}
$$

2. Rasio Aktivitas atau Turnover Ratio

Rasio aktivitas digunakan untuk menyediakan informasi bagaimana efisiensi perusahaan dalam menggunakan assetnya untuk memperoleh pendapatan. Salah satu cara mengukur rasio aktivitas adalah dengan menggunakan Receivable Turnover yang dirumuskan dengan:

\section{Receivable turnover

$$
=\frac{\text { Sales }}{\text { Account receivable }}
$$

3. Rasio Utang atau Financial Leverage Ratio

Rasio utang digunakan untuk memberikan informasi mengenai kemampuan jangka panjang perusahaan dalam memenuhi kewajibannya. Rasio utang dapat dianalisis salah satunya dengan Debt to Equity Ratio yang dirumuskan sebagai berikut:

Debt to equity ratio $=\frac{\text { Total debt }}{\text { Total equity }}$

4. Rasio Profitabilitas

Rasio profitabilitas digunakan untuk menganalisis efisiensi perusahaan dalam menggunakan asetnya atau efisiensi operasi. Salah satu jenis rasio profitabilitas ialah Return on Assets. ROA merupakan salah satu indikator performa perusahaan yang dirumuskan sebagai berikut:

5. Rasio Nilai Pasar

Return on assets $=\frac{\text { Net income }}{\text { Total assets }}$

Rasio nilai pasar dapat dianalisis dengan menggunakan Earnings Per Share (EPS), yang dirumuskan sebagai berikut:

$$
E P S=\frac{\text { Net income }}{\text { Share outstanding }}
$$

\section{Tata Kelola Perusahaan}

Asbaugh (2004) dalam Siagian, Siregar, dan Rahadian (2013) menyebutkan bahwa tata kelola perusahaan menyajikan seperangkat mekanisme yang ditujukan untuk mengurangi resiko agensi akibat adanya asimetrik informasi. Dengan tata kelola perusahaan yang baik maka biaya atas modal saham yang menyebabkan meningkatnya nilai perusahaan dapat ditekan. Ada beberapa proxy yang dapat digunakan untuk mengukur tata kelola perusahaan seperti yang digunakan dalam peneritian Anggitasari dan Mutmainah (2012), yaitu: 
1. Presentase kepemilikan saham institusional

Kepemilikan saham institusional merupakan saham yang dimiliki oleh perusahaan lain, dana pensiun, reksadana, atau institusi lain. Adhi dalam Anggitasari dan Mutmainah (2012) menyebutkan bahwa komposisi kepemilikan saham berdampak penting pada kendali perusahaan. Jika terdapat kecenderungan bahwa institusi pemegang saham menempatkan orang kepercayaannya di suatu perusahaan maka masing-masing orang yang dipercaya tersebut akan bekerja dengan mengutamakan kepentingan institusi yang mengutusnya. Hal tersebut dapat memperkecil resiko terkait konflik kepentingan manajemen dan pemegang saham. Persentase kepemilikan institusional dapat diukur dengan proporsi kepemilikan saham oleh institusi jika dibandingkan dengan total modal saham yang beredar (Suhartanti dan Asyik, 2015).

2. Persentase dewan komisaris independen

Tata kelola perusahaan di Indonesia, memisahkan peranan dewan komisaris dan dewan direksi. KNKG 2006 dalam Anggitasari dan Mutmainah (2012) menyebutkan bahwa dewan komisaris dapat terdiri dari komisaris yang tidak berasal dari pihak terafiliasi yang disebut komisaris independen. Keberadaan dewan komisaris independen dapat diukur dengan melihat persentasenya, yaitu proporsi jumlah dewan komisaris independen jika dibandingkan dengan jumlah keseluruhan dewan komisaris (Suhartanti dan Asyik, 2015)

3. Keberadaan komite audit

Komite audit adalah komite yang dibentuk oleh dewan komisaris untuk membantu tugasnya dalam mengawasi operasional perusahaan, tata kelola, serta laporan keuangan. Komite audit ini dapat beranggotakan lebih dari 1 orang untuk membantu dewan komisaris. Dengan keberadaan komite audit yang mengawasi jalannya perusahaan, diharapkan manajemen dapat menjalankan perusahaan sesuai dengan tujuan perusahaan yaitu untuk kepentingan para pemegang saham. Keberadaan komite audit dapat diukur dengan dengan banyaknya jumlah komite audit yang dimiliki perusahaan (Anggitasari, 2012).

\section{Kerangka Pemikiran}

\section{Pengaruh Current Ratio terhadap Nilai Perusahaan}

Current ratio sebagai sebagai salah satu indikator rasio likuiditas digunakan untuk menyediakan informasi mengenai kemampuan perusahaan membayar kewajiban jangka pendeknya tanpa kesulitan. Perusahaan dengan tingkat likuiditas tinggi cenderung tidak menggunakan utang untuk membiayai investasinya dan menggunakan dana internal untuk membiayai kegiatan operasi dan investasinya. Febrianti (2012) mengemukakan bahwa dengan likuiditas tinggi, investor akan melihat kemampuan perusahaan dalam mengelola pendanaannya sehingga mengundang daya tarik investor untuk berinvestasi. Semakin tinggi permintaan investor akan saham suatu perusahaan maka semakin tinggi pula harga saham yang beredar yang mencerminkan semakin tinggi pula nilai perusahaan di mata investor. Berdasarkan penelitian Febrianti (2012), diperoleh hasil bahwa secara simultan likuiditas berpengaruh signifikan terhadap nilai perusahaan. Namun, secara parsial likuiditas tidak berpengaruh signifikan terhadap nilai perusahaan. Sementara menurut penelitian Deitiana (2011), secara parsial likuiditas tidak berpengaruh signifikan terhadap harga saham yang mencerminkan nilai perusahaan. 


\section{Pengaruh Receivable Turnover terhadap Nilai Perusahaan}

Receivable turnover merupakan rasio yang memberikan gambaran bagaimana efisiensi perusahaan dalam menggunakan assetnya untuk memperoleh pendapatan. Receivable turnover yang baik memberikan gambaran bahwa siklus penjualan dari sejak barang diserahkan hingga pembayaran diterima berjalan dengan baik. Dengan siklus penjualan yang cukup, tentunya memungkinkan peluang menciptakan cash flow yang baik serta menunjukkan kinerja perusahaan yang dapat menarik investor untuk berinvestasi. Semakin tinggi permintaan investor akan saham suatu perusahaan maka semakin tinggi pula harga saham yang beredar yang mencerminkan semakin tinggi pula nilai perusahaan di mata investor. Stiyarini dan Santoso (2016) menemukan dalam penelitiannya bahwa rasio aktivitas tidak berpengaruh signifikan terhadap nilai perusahaan yang tercermin melalui harga saham. Sementara dalam penelitian Rinnaya, Andini, dan Oemar (2016) menemukan bahwa rasio aktivitas berpengaruh signifikan terhadap nilai perusahaan.

\section{Pengaruh Debt to Equity Ratio terhadap Nilai Perusahaan}

Debt to Equity Ratio (DER) merupakan rasio yang digunakan untuk melihat kemampuan perusahaan dalam jangka panjang untuk memenuhi kewajibannya. Menurut Jensen dalam Febrianti (2012), nilai perusahaan dapat meningkat dengan adanya utang apabila utang tersebut digunakan bukan untuk berinvestasi yang tidak menguntungkan tetapi untuk mengendalikan penggunaan arus kas secara berlebihan oleh pihak manajemen. Hal ini dikarenakan utang dapat menyebabkan pertumbuhan perusahaan menjadi lebih cepat dibandingkan dengan menggunakan modal sendiri. Namun jika terlalu besar, juga dapat berdampak pada kesulitan membayar kewajibannya. Febrianti (2012) menyatakan bahwa semakin rendah DER maka semakin tinggi pula kemampuan perusahaan untuk memenuhi kewajibannya. Dengan demikian perusahaan memiliki kemampuan juga untuk membagikan dividen. Tentunya hal ini menjadi daya tarik bagi investor yang dapat meningkatkan harga saham dan nilai perusahaan. Penelitian yang dilakukan oleh Febrianti (2012) dengan menggunakan DER, rasio profitabilitas, dan rasio likuiditas sebagai indikator kinerja keuangan menemukan bahwa justru DER yang memiliki pengaruh signifikan terhadap nilai perusahaan. Sementara penelitian Safitri (2013) menyatakan bahwa DER tidak berpengaruh signifikan secara parsial terhadap harga saham yang mencerminkan nilai perusahaan.

\section{Pengaruh Return on Assets terhadap Nilai Perusahaan}

Return on Assets (ROA) merupakan rasio yang dapat menganalisis kemampuan perusahaan menggunakan assetnya untuk memperoleh penghasilan. Profitabilitas yang tinggi menunjukkan prospek perusahaan yang baik sehingga cenderung memberikan sinyal positif kepada investor untuk berinvestasi. Dari penelitian Repi, Murni, dan Adare (2016), ROA berpengaruh signifikan secara simultan maupun parsial terhadap nilai perusahaan. Penelitian yang sama dengan indikator ROA juga dilakukan Welley dan Untu (2015) dengan hasil ROA berpengaruh signifikan secara simultan dan parsial terhadap nilai perusahaan. Sementara penelitian Tjandrakirana dan Monika (2014), memiliki hasil ROA yang berpengaruh signifikan secara simultan terhadap nilai perusahaan. Namun jika dilihat secara parsial, tidak berpengaruh signifikan.

\section{Pengaruh Earning Per Share terhadap Nilai Perusahaan}

Earning per share (EPS) merupakan rasio untuk melihat besarnya laba untuk setiap lembar saham. Nilai EPS yang tinggi 
mencerminkan bagian laba yang tinggi untuk masing-masing lembar saham. Tentunya hal tersebut mencerminkan kinerja perusahaan yang baik sehingga mengundang daya tarik investor untuk berinvestasi. Sehingga dapat dikatakan bahwa EPS memiliki pengaruh terhadap nilai perusahaan. Safitri (2013) menemukan bahwa EPS berpengaruh signifikan secara parsial dan simultan terhadap harga saham yang mencerminkan nilai perusahaan. Kenaikan EPS akan mendorong investor untuk berinvestasi sehingga meningkatkan harga saham. Namun hasil yang berbeda diperoleh dalam penelitian Pesiwarissa dan Simus (2014) yang menemukan bahwa EPS tidak berpengaruh signifikan secara parsial terhadap nilai perusahaan.

\section{Pengaruh Tata Kelola Perusahaan terhadap Nilai Perusahaan}

Adhi dalam Anggitasari dan Mutmainah (2012) menyebutkan bahwa komposisi kepemilikan saham memiliki dampak penting pada kendali perusahaan. Jika dalam perusahaan, institusi pemegang saham menempatkan orang kepercayaannya dalam manajemen maka konflik kepentingan akan cenderung dapat diperkecil. Kondisi ini tentunya menyebabkan kepentingan pemegang saham menjadi terlindungi sehingga memberikan daya tarik bagi investor yang dapat mempengaruhi nilai perusahaan. Penelitian Suhartanti dan Asyik (2015) serta Siagian, Siregar, dan Rahadian (2013) menarik kesimpulan bahwa persentase kepemilikan institusional berpengaruh signifikan terhadap nilai perusahaan. Demikian juga hasil yang serupa ditemukan pada penelitian Anggitasari dan Mutmainah (2012), Sementara penelitian Dewi dan Nugrahanti (2014), persentase kepemilikan institusional tidak berpengaruh signifikan terhadap nilai perusahaan.

\section{Pengaruh Persentase Dewan Komisaris} Independen terhadap Nilai Perusahaan

Komisaris independen menurut Anggitasari dan Mutmainah (2012) merupakan pihak yang tidak memiliki hubungan afiliasi dengan perusahaan. Komisaris independen dapat menjadi penengah jika terjadi perselisihan internal antara dewan komisaris ataupun dewan direksi. Dengan adanya komisaris independen, maka investor individual akan cenderung lebih terlindungi kepentingannya, sehingga dapat meningkatkan kepercayaan investor untuk berinvestasi dan meningkatkan nilai perusahaan. Dari penelitian terdahulu Prameswari (2016), Suhartanti dan Asyik (2015), serta Siagian, Siregar, dan Rahadian (2013) dapat disimpulkan bahwa keberadaan dewan komisaris independen memiliki pengaruh signifikan positif terhadap nilai perusahaan. Demikian pula dengan hasil penelitian Dewi dan Nugrahanti (2014) yang menyatakan bahwa keberadaan dewan komisaris independen memiliki pengaruh signifikan secara parsial terhadap nilai perusahaan. Sementara penelitian Anggitasari dan Mutmainah (2012), keberadaan dewan komisaris independen tidak menunjukkan pengaruh yang signifikan.

\section{Pengaruh Keberadaan Komite Audit terhadap Nilai Perusahaan}

Keberadaan komite audit yang ditunjuk oleh Dewan Komisaris, bertugas untuk mengawasi jalannya perusahaan, baik secara operasional, tata kelola, maupun secara finansial. Dengan keberadaan komite audit diharapkan manajemen dapat menjalankan perusahaan sesuai dengan tujuan perusahaan yaitu untuk kepentingan para pemegang saham. Jaminan perlindungan kepentingan ini juga dapat menjadi daya tarik bagi investor untuk berinvestasi, sehingga dapat meningkatkan nilai perusahaan. Dari penelitian sebelumnya, penelitian Suhartanti dan Asyik (2015) serta Siagian, Siregar, dan Rahadian (2013) dapat ditarik keimpulan 
bahwa keberadaan komite audit memiliki pengaruh signifikan positif terhadap nilai perusahaan. Sementara pada penelitian Anggitasari dan Mutmainah (2012) keberadaan komite audit tidak menunjukkan pengaruh yang signifikan.

\section{Model Penelitian}

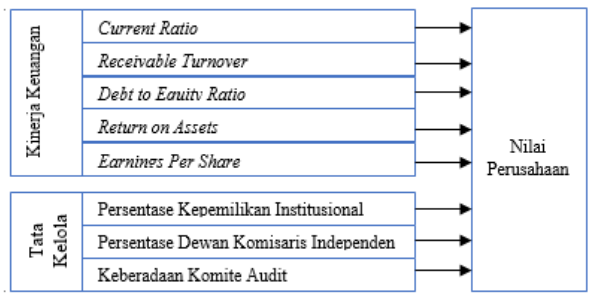

Gambar 1

Model Penelitian

Sumber: Penulis, 2016

\section{Hipotesis}

Dalam penelitian ini terdapat sembilan hipotesis yang diuji dengan menggunakan bantuan SPSS 20. Hipotesis pertama adalah current ratio berpengaruh signifikan secara parsial terhadap nilai perusahaan $\left(\mathrm{H}_{1}\right)$. Hipotesis kedua adalah receivable turnover berpengaruh signifikan secara parsial terhadap nilai perusahaan $\left(\mathrm{H}_{2}\right)$. Hipotesis ketiga adalah debt to equity ratio berpengaruh signifikan secara parsial terhadap nilai perusahaan $\left(\mathrm{H}_{3}\right)$. Hipotesis keempat adalah return on assets berpengaruh signifikan secara parsial terhadap nilai perusahaan $\left(\mathrm{H}_{4}\right)$. Hipotesis kelima adalah earnings per share berpengaruh signifikan secara parsial terhadap nilai perusahaan $\left(\mathrm{H}_{5}\right)$. Hipotesis keenam adalah persentase kepemilikan institusional berpengaruh signifikan secara parsial terhadap nilai perusahaan $\left(\mathrm{H}_{6}\right)$. Hipotesis ketujuh adalah persentase dewan komisaris independen berpengaruh signifikan secara parsial terhadap nilai perusahaan $\left(\mathrm{H}_{7}\right)$. Hipotesis kedelapan adalah keberadaan komite audit berpengaruh signifikan secara parsial terhadap nilai perusahaan $\left(\mathrm{H}_{8}\right)$. Hipotesis kesembilan adalah current ratio, receivable turnover, debt to equity ratio, return on assets, earning per share, persentase kepemilikan institusional, persentase dewan komisaris independen, dan keberadaan komite audit berpengaruh signifikan secara simultan terhadap nilai perusahaan $\left(\mathrm{H}_{9}\right)$.

\section{Metode Penelitian}

\section{Metode Penelitian Populasi dan Sampel}

Penelitian ini merupakan causal research yang mencoba mencari pengaruh suatu variabel terhadap variabel lainnya. Pengambilan sampel dilakukan dengan pendekatan purposive sampling. Dalam sub sektor telekomunikasi yang terdaftar di bursa terdapat 6 perusahaan telekomunikasi sebagai populasi, namun pengambilan sampel dilakukan terhadap 4 emiten yaitu: PT Smartfren Telecom Tbk, PT Indosat Tbk, PT Telkom Indonesia Tbk, dan PT XL Axiata Tbk. Kedua emiten lainnya, yaitu PT Bakrie Telecom Tbk dan PT Inovisi Infracom Tbk sahamnya di-suspend sehingga harga saham tidak dapat menunjukkan harga yang wajar.

\section{Teknik Pengumpulan Data}

Dalam penelitian ini digunakan teknik pengumpulan data melalui studi kepustakaan yang diperoleh melalui buku teks, literatur, serta jurnal-jurnal penelitian terdahulu. Selain itu dilakukan pula pengumpulan data sekunder melalui website resmi Bursa Efek Indonesia (www.idx.co.id) maupun website resmi perusahan-perusahaan industri telekomunikasi yang terdaftar di BEI.

\section{Teknik Analisis Data}

Pengolahan data dalam penelitian ini menggunakan analisis regresi linear berganda dengan bantuan Software SPSS 20. Model regresi yang baik harus memenuhi empat uji asumsi klasik, yang meliputi: uji multikolinieritas, uji 
heteroskedastisitas, uji normalitas, dan uji autokorelasi.

\section{Uji Normalitas}

Menurut Ghozali (2011), uji normalitas bertujuan untuk menguji apakah dalam model regresi, variabel pengganggu atau residual berdistribusi normal. Uji normalitas dapat dilakukan dengan Uji Kolmogorov Smirnov. Jika nilai $\mathrm{Z}$ Kolmogorov Smirnov lebih besar dari nilai signifikan artinya data residual tidak berdistribusi normal. Jika nilai $Z$ Kolmogorov Smirnov lebih kecil dari nilai signifikan artinya data residual berdistribusi normal.

\section{Uji Heteroskedastisitas}

Menurut Ghozali (2011), uji heteroskedastisitas bertujuan untuk menguji apakah dalam model regresi terjadi ketidaksamaan varians dari residual satu pengamatan ke pengamatan lainnya. Uji heteroskedastisitas dapat dilakukan dengan Uji Glejser. Model regresi yang bebas dari heteroskedastisitas ialah jika nilai signifikansi Uji Glejser dari masing-masing variabel independen lebih besar dari taraf signifikansi penelitian.

\section{Uji Multikolinearitas}

Uji multikolinearitas menurut Ghozali (2011) bertujuan untuk menguji apakah dalam model regresi ditemukan adanya korelasi antar variabel bebas. Model regresi yang baik seharusnya tidak ditemukan korelasi di antara variabel independen. Salah satu cara yang dapat digunakan untuk menguji multikolinieritas adalah dengan menggunakan matrix correlation untuk melihat korelasi antar variabel independen. Ghozali dan Ratmono (2013) menyebutkan bahwa korelasi diantara dua variabel independen yang melebihi 0,80 dapat menjadi pertanda bahwa terdapat multikolinearitas dalam model regresi.

\section{Uji Autokorelasi}

Menurut Ghozali (2011), uji autokorelasi bertujuan menguji apakah di dalam model regresi linear terdapat korelasi antara kesalahan pengganggu pada periode $t$ dengan kesalahan pengganggu pada periode $\mathrm{t}-1$ (sebelumnya). Uji statistik yang digunakan adalah Runs Test. Apabila nilai signifikansi Runs Test lebih besar daripada taraf signifikansi penelitian $(\alpha)$ maka dapat diartikan tidak terdapat autokorelasi dalam model regresi linear.

\section{Analisis Regresi Berganda}

Jika uji asumsi klasik telah terpenuhi, maka selanjutnya dapat dilanjutkan dengan uji hipotesis. Adapun model regresi dari penelitian ini adalah:

$$
\begin{aligned}
Y & =\beta 0+\beta 1 \times 1+\beta 2 \times 2+\beta 3 \times 3+\beta 4 X 4 \\
& +\beta 5 \times 5+\beta 6 \times 6+\beta 7 \times 7+\beta 8 \times 8+\varepsilon
\end{aligned}
$$

di mana:

$\mathrm{Y} \quad=$ nilai perusahaan

$\mathrm{X}_{1} \quad=$ current ratio

$\mathrm{X}_{2} \quad=$ receivable turnover

$\mathrm{X}_{3} \quad=$ debt to equity ratio

$\mathrm{X}_{4} \quad=$ return on assets

$\mathrm{X}_{5} \quad=$ earnings per share

$\mathrm{X}_{6} \quad=$ persentase kepemilikan institusional

$\mathrm{X}_{7} \quad=$ persentase dewan komisaris independen

$\mathrm{X}_{8} \quad=$ keberadaan komite audit

$\beta_{0} \quad=$ konstanta

$\beta_{1}-\beta_{8}=$ koefisien variabel

$\varepsilon \quad=$ error

Setelah dilakukan uji asumsi klasik, hipotesis dalam penelitian ini kemudian diuji menggunakan uji signifikansi parsial dengan uji-t dan menggunakan uji signifikansi simultan dengan uji $\mathrm{F}$.

\section{Uji Signifikansi Parsial (uji-t)}

Menurut Ghozali (2011), uji t atau uji pengaruh parsial digunakan untuk mengetahui pengaruh masing-masing variabel independen terhadap variabel 
dependen. Jika nilai sig >0,05 maka dapat dinyatakan bahwa variabel independen secara parsial tidak berpengaruh terhadap variabel dependen. Sementara jika nilai signifikansi $\leq 0,05$ maka dapat dikatakan bahwa secara parsial variabel independen berpengaruh signifikan terhadap variabel independen.

\section{Uji Signifikansi Simultan (uji F)}

Menurut Ghozali (2011), uji F atau uji pengaruh simultan digunakan untuk mengetahui apakah variabel independen secara bersama-sama atau simultan mempengaruhi variabel dependen. Jika nilai sig > 0,05 maka dapat dinyatakan variabel variabel independen tidak berpengaruh secara simultan terhadap variabel dependen. Sementara jika nilai sig $\leq 0,05$ maka dapat dikatakan bahwa seluruh variabel independen memiliki pengaruh signifikan terhadap variabel independen secara simultan.

\section{Hasil Penelitian dan Pembahasan}

\section{Uji Asumsi Klasik}

Uji asumsi klasik pada analisis regresi linier berganda biasanya melibatkan empat jenis uji, yaitu: uji normalitas, uji heteroskedastisitas, uji multikolinearitas, dan uji autokorelasi. Dalam penelitian ini uji asumsi klasik dilakukan dengan menggunakan alat bantu berupa software SPSS 20. Hasil uji asumsi klasik tersebut akan dibahas lebih lanjut di bawah ini.

\section{Uji Normalitas}

Dalam penelitian ini, uji normalitas dilakukan dengan menggunakan OneSample Kolmogorov-Smirnov Test. Jika dari hasil uji diperoleh nilai $Z$ KolmogorovSmirnov > nilai signifikansi maka data residual model regresi tersebut tidak berdistribusi normal. Tetapi jika dari hasil uji diperoleh nilai $Z$ Kolmogorov-Smirnov < nilai signifikansi maka data residual model regresi tersebut berdistribusi normal. Tabel
1 berikut ini merupakan output hasil uji normalitas.

Tabel 1

Hasil Uji Normalitas

One-Sample Kolmogorov-Smirnov Test

\begin{tabular}{|ll|r|}
\hline & & $\begin{array}{c}\text { Unstandardized } \\
\text { Residual }\end{array}$ \\
\hline $\mathrm{N}$ & Mean & 24 \\
Normal & Std. \\
Parameters ${ }^{\mathrm{a}, \mathrm{b}}$ & Std & Deviation \\
& Absolute & .091 \\
Most Extreme & Positive & .090 \\
Differences & Negative & -.091 \\
Kolmogorov-Smirnov Z & .447 \\
Asymp. Sig. (2-tailed) & .988 \\
\hline
\end{tabular}

a. Test distribution is Normal

b. Calculated from data.

Sumber: Output IBM SPSS 20

Dengan melihat hasil uji Normalitas dengan One-Sample Kolmogorov-Smirnov Test pada tabel di atas, diperoleh nilai $Z$ Kolmogorov-Smirnov sebesar 0,447 dan nilai signifikansi dengan two tailed test sebesar 0,988. Nilai $Z$ Kolmogorov-Smirnov $<$ nilai signifikansi dengan two tailed test. Dengan demikian dapat disimpulkan bahwa data residual model regresi linear berganda dalam penelitian ini berdistribusi normal.

\section{Uji Heteroskedastisitas}

Hasil uji heteroskedastisitas dapat dilihat pada Tabel 2 berikut ini. 
Tabel 2

Hasil Uji Heteroskedastisitas

Coefficients $^{\mathrm{a}}$

\begin{tabular}{|l|r|r|r|r|r|}
\hline \multirow{2}{*}{ Model } & \multicolumn{2}{|c|}{$\begin{array}{c}\text { Unstandardized } \\
\text { Coefficients }\end{array}$} & $\begin{array}{c}\text { Standardized } \\
\text { Coefficients }\end{array}$ & \multirow{2}{*}{ Sig. } \\
\cline { 2 - 4 } & \multicolumn{1}{|c|}{$\mathrm{B}$} & \multicolumn{1}{c|}{ Std. Error } & \multicolumn{1}{c|}{ Beta } & & \\
\hline (Constant) & -1919.194 & 3015.915 & & -.636 & .534 \\
Current_Ratio & 895.636 & 1230.977 & .386 & .728 & .478 \\
Receivable_Turnover & 42.209 & 27.384 & .441 & 1.541 & .144 \\
Debt_to_Equity_Ratio & -161.133 & 388.493 & -.225 & -.415 & .684 \\
Return_On_Assets & -1317.213 & 6427.703 & -.155 & -.205 & .840 \\
Earning_Per_Shares & .113 & 1.109 & .032 & .102 & .920 \\
Kepemilikan_Institusional & 768.310 & 2657.107 & .132 & .289 & .776 \\
Komisaris_Independen & 881.876 & 2192.313 & .107 & .402 & .693 \\
Komite_Audit & 195.569 & 270.293 & .279 & .724 & .480 \\
\hline
\end{tabular}

a. Dependent Variable: ABS_RES

Sumber: Output IBM SPSS 20

Dalam penelitian ini, uji heteroskedastisitas dilakukan dengan menggunakan metode Glejser dengan bantuan SPSS 20. Apabila hasil dari uji heteroskedastisitas dengan metode Glejser menunjukkan nilai signifikansi < nilai alpha $(0,05)$, maka dapat disimpulkan bahwa model regresi bersifat heteroskedastisitas. Sementara bila hasil dari uji heteroskedastisitas dengan metode Glejser menunjukkan nilai signifikansi > nilai alpha $(0,05)$ maka dapat disimpulkan bahwa model regresi bersifat homoskedastisitas. Dengan memperhatikan Tabel 2, diketahui bahwa nilai signifikansi dari seluruh variabel independen $>$ nilai alpha (0,05). Dengan demikian dapat disimpulkan bahwa tidak terjadi heteroskedastisitas pada model regresi linear berganda dalam penelitian ini atau dengan kata lain model regresi memiliki sifat homoskedastisitas.

\section{Uji Multikolinearitas}

Salah satu cara yang dapat digunakan untuk mendeteksi multikolinieritas adalah dengan menggunakan matrix correlation untuk mengukur korelasi antar variabel independen. Ghozali dan Ratmono (2013) menyebutkan bahwa korelasi diantara dua variabel independen yang melebihi 0,80 dapat menjadi pertanda bahwa multikolinearitas merupakan masalah serius. Dengan demikian, jika di antara dua variabel independen dalam model regresi memiliki koefisien korelasi > 0,80 dapat dikatakan bahwa dalam model regresi linear berganda tersebut terdapat multikolinearitas. Namun apabila koefisien korelasi < 0,80 maka dapat dikatakan bahwa dalam model regresi linear berganda tersebut tidak terdapat multikolinearitas. Tabel 3 berikut menampilkan hasil uji multikolinearitas. 
Tabel 3

Hasil Uji Multikolinearitas

Coefficient Correlations ${ }^{\text {a }}$

\begin{tabular}{|c|c|c|c|c|c|c|c|c|}
\hline Model & $\underset{\text { dit }}{\text { KomiteAu }}$ & $\begin{array}{l}\text { Komisari } \\
\text { s } \\
\text { Independ } \\
\text { en }\end{array}$ & $\begin{array}{l}\text { Receiva } \\
\text { ble } \\
\text { Turnove } \\
\text { r }\end{array}$ & EPS & $\begin{array}{c}\text { Kepemi } \\
\text { likan } \\
\text { Institusi } \\
\text { onal }\end{array}$ & $\begin{array}{c}\mathrm{DE} \\
\mathrm{R}\end{array}$ & $\begin{array}{c}\text { Curre } \\
\text { nt } \\
\text { Ratio }\end{array}$ & $\begin{array}{c}\text { RO } \\
\mathrm{A}\end{array}$ \\
\hline Komite_Audit & 1.000 & .078 & .229 & .248 & .049 & .070 & .044 & .496 \\
\hline $\begin{array}{l}\text { Komisaris_Independe } \\
\mathrm{n}\end{array}$ & .078 & 1.000 & -.342 & .048 & -.476 & .336 & -.391 & .195 \\
\hline Receivable_Turnover & .229 & -.342 & 1.000 & .079 & .461 & .281 & .554 & .031 \\
\hline 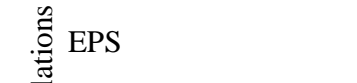 & 248 & -.048 & .079 & $\begin{array}{r}1.00 \\
0\end{array}$ & .097. & .206 & .299 & .611 \\
\hline $\begin{array}{l}1 \stackrel{\bar{\Xi}}{\mathscr{D}} \text { Kepemilikan_Institusi } \\
\text { U onal }\end{array}$ & .049 & -.476 & .461 & .097 & 1.000 & .091 & .724 & .055 \\
\hline DER & -.070 & -.336 & .281 & .206 & .091 & $\begin{array}{r}1.00 \\
0\end{array}$ & .151 & .688 \\
\hline Current_Ratio & .044 & -.391 & .554 & .299 & .724 & .151 & 1.000 & .199 \\
\hline ROA & -.496 & -.195 & .031 & .611 & .055 & .688 & -.199 & 1.00 \\
\hline
\end{tabular}

a. Dependent Variable: Nilai_Perusahaan

Sumber: Output IBM SPSS 20

Berdasarkan hasil uji multikolinearitas terhadap model regresi penelitian, diperoleh hasil bahwa antar variabel independen memiliki koefisien korelasi $<0,80$. Dengan demikian dapat disimpulkan bahwa pada model regresi linear berganda dari penelitian ini tidak terjadi multikolinearitas.

\section{Uji Autokorelasi}

Salah satu cara untuk mendeteksi autokorelasi adalah dengan menggunakan run test. Dari hasil run test, autokorelasi dapat dideteksi dengan memperhatikan nilai Asymp. Sig dengan two tailed test. Apabila nilai Asymp. Sig dengan two tailed test < nilai alpha $(0,05)$ maka terdapat gejala autokorelasi dalam model regresi. Sementara jika nilai Asymp. Sig dengan two tailed test < nilai alpha $(0,05)$ maka dapat disimpulkan tidak terdapat gejala autokorelasi. Tabel 4 berikut ini menampilkan hasil uji autokorelasi dengan bantuan SPSS 20. 
Tabel 4

Hasil Uji Autokorelasi

Runs Test

\begin{tabular}{|l|r|}
\hline & \multicolumn{1}{|c|}{ Unstandardized Residual } \\
\hline Test Value $^{\mathrm{a}}$ & 29,11238 \\
Cases < Test Value & 12 \\
Cases >= Test Value & 12 \\
Total Cases & 24 \\
Number of Runs & 11 \\
Z &,- 626 \\
Asymp. Sig. (2-tailed) &, 531 \\
\hline
\end{tabular}

a. Median

Sumber: Output IBM SPSS 20

Berdasarkan Tabel 4 diperoleh nilai Asymp. Sig dengan two tailed test sebesar 0,531 yang menunjukkan bahwa nilai Asymp. Sig dengan two tailed test $>$ nilai alpha $(0,05)$. Dengan demikian maka dapat disimpulkan bahwa pada model regresi linear berganda dalam penelitian ini tidak terdapat gejala autokorelasi.

\section{Hasil Pengujian Hipotesis}

Untuk menguji $\mathrm{H}_{1}, \mathrm{H}_{2}, \mathrm{H}_{3}, \mathrm{H}_{4}, \mathrm{H}_{5}, \mathrm{H}_{6}, \mathrm{H}_{7}$, dan $\mathrm{H}_{8}$ digunakan uji signifikansi parsial dengan uji-t yang menunjukkan besarnya pengaruh masing-masing variabel independen terhadap variabel dependen secara parsial. Sementara untuk menguji $\mathrm{H}_{9}$ digunakan uji signifikansi simultan dengan uji $\mathrm{F}$ yang menunjukkan besarnya pengaruh seluruh variabel independen secara simultan terhadap variabel dependen. Hasil uji-t dan uji $\mathrm{F}$ terkait penelitian ini akan dijelaskan lebih lanjut di bawah ini.

\section{Uji Signifikansi Parsial (uji-t)}

Ghozali (2011) menuturkan bahwa uji-t atau uji pengaruh parsial digunakan untuk mengetahui pengaruh masing-masing variabel independen terhadap variabel dependen dalam suatu model regresi. Pengaruh masing-masing variabel dapat dideteksi dengan melihat nilai signifikansi dari hasil uji-t. Jika berdasarkan hasil uji-t nilai signifikansi > nilai alpha $(0,05)$ maka dapat dikatakan bahwa variabel independen tidak berpengaruh signifikan terhadap variabel dependen. Sementara jika dari hasil uji-t diperoleh nilai signifikansi $\leq$ nilai alpha $(0,05)$ maka dapat dikatakan bahwa variabel independen berpengaruh signifikan terhadap variabel independen. Hasil uji-t atau uji parsial terhadap model regresi linear berganda dalam penelitian ini dapat dilihat pada Tabel 5 berikut ini. 


\section{Tabel 5}

\section{Hasil Uji Hipotesis dengan Uji-t}

Coefficients $^{\mathrm{a}}$

\begin{tabular}{|l|r|r|r|r|r|}
\hline \multirow{2}{*}{ Model } & \multicolumn{2}{|c|}{$\begin{array}{c}\text { Unstandardized } \\
\text { Coefficients }\end{array}$} & $\begin{array}{c}\text { Standardized } \\
\text { Coefficients }\end{array}$ & \multicolumn{1}{c|}{ Sig. } \\
\cline { 2 - 4 } & \multicolumn{1}{|c|}{ B } & Std. Error & \multicolumn{1}{c|}{ Beta } & & \\
\hline (Constant) & $-1666,437$ & 6083,914 & &,- 274 &, 788 \\
Current_Ratio & $-988,265$ & 2483,212 &,- 146 &,- 398 &, 696 \\
Receivable_Turnover & $-34,602$ & 55,241 &,- 124 &,- 626 &, 540 \\
Debt_to_Equity_Ratio & 461,569 & 783,694 &, 222 &, 589 &, 565 \\
Return_On_Assets & 27499,195 & 12966,411 & 1,114 & 2,121 &, 048 \\
Earning_Per_Shares & $-1,297$ & 2,237 &,- 128 &,- 580 &, 571 \\
Kepemilikan_Institusional & 12268,559 & 5360,101 &, 722 & 2,289 &, 037 \\
Komisaris_Independen & $-11378,578$ & 4422,487 &,- 473 & $-2,573$ &, 021 \\
Komite_Audit & 314,584 & 545,253 &, 154 &, 577 &, 573 \\
\hline
\end{tabular}

a. Dependent Variable: Nilai_Perusahaan

Sumber: Output IBM SPSS 20

Dengan melihat tabel hasil uji-t di atas, diperoleh informasi bahwa nilai signifikansi dari variabel current ratio adalah sebesar $0,696>$ nilai alpha $(0,05)$. Artinya variabel current ratio tidak berpengaruh signifikan secara parsial terhadap nilai perusahaan. Dengan kata lain berdasarkan hasil uji-t dapat disimpulkan bahwa $\mathrm{H}_{1}$ ditolak.

Nilai signifikansi dari variabel receivable turnover adalah sebesar $0,540>$ nilai alpha $(0,05)$. Artinya variabel receivable turnover tidak berpengaruh signifikan secara parsial terhadap nilai perusahaan. Dengan kata lain berdasarkan hasil uji-t dapat disimpulkan bahwa $\mathrm{H}_{2}$ ditolak.

Nilai signifikansi dari variabel debt to equity ratio ialah sebesar $0,565>$ nilai alpha $(0,05)$. Artinya variabel debt to equity ratio tidak berpengaruh signifikan secara parsial terhadap nilai perusahaan. Dengan kata lain berdasarkan hasil uji-t dapat disimpulkan bahwa $\mathrm{H}_{3}$ ditolak.

Nilai signifikansi dari variabel return on assets ialah sebesar $0,048<$ nilai alpha $(0,05)$. Artinya variabel return on assets berpengaruh signifikan secara parsial terhadap nilai perusahaan. Dengan kata lain berdasarkan hasil uji-t disimpulkan bahwa $\mathrm{H}_{4}$ dapat diterima.
Nilai signifikansi dari variabel earning per shares ialah sebesar $0,571>$ nilai alpha $(0,05)$. Artinya variabel earning per shares tidak berpengaruh signifikan secara parsial terhadap nilai perusahaan. Dengan kata lain berdasarkan hasil uji-t disimpulkan bahwa $\mathrm{H}_{5}$ ditolak.

Nilai signifikansi dari variabel persentase kepemilikan institusional ialah sebesar $0,037<$ nilai alpha $(0,05)$. Artinya variabel persentase kepemilikan institusional berpengaruh signifikan secara parsial terhadap nilai perusahaan. Dengan kata lain berdasarkan hasil uji-t disimpulkan bahwa $\mathrm{H}_{6}$ dapat diterima. Nilai signifikansi dari variabel persentase dewan komisaris independen ialah sebesar $0,021<$ nilai alpha $(0,05)$. Artinya variabel persentase dewan komisaris independen berpengaruh signifikan secara parsial terhadap nilai perusahaan. Dengan kata lain berdasarkan hasil uji-t disimpulkan bahwa $\mathrm{H}_{7}$ dapat diterima.

Nilai signifikansi dari variabel keberadaan komite audit ialah sebesar $0,573>$ nilai alpha $(0,05)$. Artinya variabel keberadaan komite audit tidak berpengaruh signifikan secara parsial terhadap nilai perusahaan. 
Dengan kata lain berdasarkan hasil uji-t disimpulkan bahwa $\mathrm{H}_{8}$ ditolak.

\section{Uji Signifikansi Simultan (Uji-F)}

Ghozali (2011) menuturkan bahwa uji F atau uji pengaruh simultan digunakan untuk mengetahui apakah variabel independen dalam suatu model regresi secara bersamasama atau simultan mempengaruhi variabel dependen. Pengaruh tersebut dapat dideteksi dengan memperhatikan nilai signifikansi dari hasil uji F. Apabila nilai signifikansi > alpha $(0,05)$ maka dapat dinyatakan bahwa variabel - variabel independen tidak berpengaruh secara simultan terhadap variabel dependen. Sementara jika nilai signifikansi $\leq$ alpha $(0,05)$ maka dapat dikatakan bahwa seluruh variabel independen memiliki pengaruh signifikan terhadap variabel independen secara simultan. Hasil uji $F$ atau uji simultan terhadap model regresi linear berganda dalam penelitian ini dapat dilihat pada Tabel 6 berikut ini.

Tabel 6

Hasil Uji Hipotesis dengan Uji-t ANOVA $^{\mathrm{a}}$

\begin{tabular}{|l|r|r|r|r|r|}
\hline Model & \multicolumn{1}{|c|}{ Sum of Squares } & \multicolumn{1}{c|}{ df } & Mean Square & F & Sig. \\
\hline Regression & 77142294,04 & 8 & 9642786,76 & 3,845 &, $012^{\text {b }}$ \\
1 Residual & 37614051,92 & 15 & 2507603,46 & & \\
Total & 114756345,96 & 23 & & & \\
\hline
\end{tabular}

a. Dependent Variable: Nilai_Perusahaan

b. Predictors: (Constant), Komite_Audit, Komisaris_Independen, Receivable_Turnover, Earning_Per_Shares, Kepemilikan_Institusional, Debt_to_Equity_Ratio, Current_Ratio, Return_On_Assets

Sumber: Output IBM SPSS 20

Dengan memperhatikan tabel di atas diperoleh informasi bahwa nilai signifikansi dari model regresi ialah 0,012. Nilai signifikansi sebesar $0,012<$ alpha $(0,05)$. Dengan kata lain berdasarkan hasil uji-F dengan metode ANOVA dapat disimpulkan bahwa $\mathrm{H}_{9}$ diterima. Artinya current ratio, receivable turnover, debt to equity ratio, return on assets, earning per share, persentase kepemilikan institusional, persentase dewan komisaris independen, dan keberadaan komite audit berpengaruh signifikan secara simultan terhadap nilai perusahaan.

\section{Pembahasan}

Berdasarkan uji hipotesis yang telah dilakukan, uji signifikansi parsial dan simultan menunjukkan bahwa:
1. $\mathrm{H}_{1}$ ditolak. Artinya current ratio tidak berpengaruh signifikan secara parsial terhadap nilai perusahaan. Hasil penelitian ini sejalan dengan penelitian Deitiana (2011) yang mengemukakan bahwa likuiditas tidak berpengaruh signifikan secara parsial terhadap harga saham yang mencerminkan nilai perusahaan. Tidak selamanya likuiditas menjadi sinyal positif bagi investor. Holdet (1988) dalam Destiana (2011) melihat adanya upaya perusahaan menurunkan rasio pembayaran dividen untuk meningkatkan likuiditas. Hal ini dikarenakan dividen akan mempengaruhi kebijakan pendanaan perusahaan karena akan mengurangi kas dan mendorong perusahaan mengeluarkan sekuritas baru. Bagi investor yang tujuannya berinvestasi 
jangka panjang, pendapatan dari dividen menjadi penting. Dan likuiditas bisa dipandang sebagai sinyal yang kurang baik sehingga timbul keraguan bagi investor untuk berinvestasi.

2. $\mathrm{H}_{2}$ ditolak. Artinya turnover receivable tidak berpengaruh signifikan secara parsial terhadap nilai perusahaan. Penelitian ini sesuai dengan hasil penelitian Stiyarini dan Santoso (2016) yang menemukan bahwa rasio aktivitas tidak berpengaruh signifikan terhadap nilai perusahaan yang tercermin melalui harga saham. Turnover receivable mengukur kemampuan perusahaan melaksanakan aktivitasnya sehari-hari dengan mengumpulkan piutang. Akan tertapi hal tersebut menjadi suatu kekhawatiran bagi investor jika nilai piutang tersebut tidak dapat segera dikonversi menjadi cash. Karenanya rasio aktivitas kurang mempengaruhi keputusan investor untuk berinvestasi.

3. $\mathrm{H}_{3}$ ditolak. Artnya debt to equity ratio tidak berpengaruh signifikan secara parsial terhadap nilai perusahaan. Penelitian ini sejalan dengan penelitian yang dilakukan oleh Safitri (2013). DER tidak menjadi faktor yang diperhatikan oleh investor ketika akan berinvestasi sebab sudah menjadi kewajaran bahwa perusahaan menggunakan 2 macam modal untuk menjalankan usahanya, yaitu dengan modal internal dan modal eksternal (hutang). Perusahaan sendiri lebih menyukai modal internal sehingga perusahaan yang pendapatannya tinggi cenderung meminjam dalam jumlah sedikit dan perusahaan dengan pendapatan yang sedikit cenderung menggunakan modal utang. DER tidak menjadi patokan bagi investor karena setiap perusahaan pasti memiliki pendanaan eksternal meskipun dengan proporsi yang berbeda. Selain itu selama perusahaan benar-benar mampu mengelola modal eksternal tersebut untuk menciptakan profit, maka DER yang tinggi, asalkan masih dalam koridor ketentuan bagi emiten, tidak menjadi kekhawatiran bagi investor sehingga tidak mempengaruhi harga saham yang mencerminkan nilai perusahaan.

4. $\mathrm{H}_{4}$ dapat diterima. Artinya return on assets berpengaruh signifikan secara parsial terhadap nilai perusahaan. Hasil penelitian ini didukung juga oleh penelitian sebelumnya yang dilakukan oleh Welley dan Untu (2016) yang menemukan bahwa profitabilitas yang diukur dengan ROA berpengaruh signifikan secara parsial terhadap nilai perusahaan. Penelitian ini juga sesuai dengan hasil penelitian Repi, Murni, dan Adare (2016). Profitabilitas masih menjadi sinyal positif bagi perusahaan untuk menarik investor. Hal ini disebabkan karena profitabilitas memberikan gambaran keberhasilan yang diraih perusahaan serta prospek perusahaan di masa mendatang. Sinyal positif ini menarik investor untuk berinvestasi sehingga meningkatkan harga saham yang mencerminkan nilai perusahaan.

5. $\mathrm{H}_{5}$ ditolak. Artinya earning per share tidak berpengaruh signifikan secara parsial terhadap nilai perusahaan. Hasil penelitian ini sesuai dengan penelitian Pesiwarissa dan Simus (2014) yang menyatakan bahwa EPS tidak berpengaruh signifikan secara parsial terhadap nilai perusahaan. Hal ini dikarenakan jumlah EPS yang dilaporkan perusahaan cenderung berbeda dengan dividen yang dibagikan kepada para pemegang saham. Seringkali perusahaan menahan labanya dan tidak membagikan dalam bentuk dividen dengan tujuan ekspansi yang mengakibatkan dividen yang dibagikan menjadi lebih kecil. EPS tidak cukup meyakinkan investor 
dalam menilai perusahaan sehingga tidak berpengaruh terhadap keputusan investasi mereka.

6. $\mathrm{H}_{6}$ dapat diterima. Artinya persentase kepemilikan institusional berpengaruh signifikan secara parsial terhadap nilai perusahaan. Hasil penelitian ini sejalan dengan penelitian yang dilakukan oleh Suhartanti dan Asyik (2015) serta Anggitasari dan Mutmainah (2012). Komposisi saham berpengaruh penting dalam sistem kendali perusahaan. Sistem kendali yang baik mengindikasikan meningkatnya kinerja keuangan yang baik. Semakin tinggi kepemilikan saham oleh institusi maka semakin tinggi pula intensitas institusi secara profesional dalam memantau investasinya agar dapat menghasilkan keuntungan yang diharapkan. Tentunya hal ini akan menarik minat investor-investor baru yang akan meningkatkan harga saham yang mencerminkan meningkatnya nilai perusahaan.

7. $\mathrm{H}_{7}$ dapat diterima. Artinya persentase dewan komisaris independen berpengaruh signifikan secara parsial terhadap nilai perusahaan. Hasil penelitian ini sesuai dengan hasil penelitian Dewi dan Nugrahanti (2014), yang menyatakan bahwa dewan komisaris independen berpengaruh signifikan secara parsial terhadap nilai perusahaan. Keberadaan dewan komisaris independen dipercaya dapat meningkatkan efektifitas pengawasan dan mengupayakan meningkatkan kinerja serta mengurangi kecurangan dalam pelaporan. Kualitas pelaporan dan kepercayaan terhadap kinerja perusahaan mendorong investor untuk berinvestasi sehingga dapat meningkatkan nilai perusahaan.

8. $\mathrm{H}_{8}$ ditolak. Artinya keberadaan komite audit tidak berpengaruh signifikan secara parsial terhadap nilai perusahaan. Hasil penelitian ini sejalan dengan penelitian Anggitasari dan Mutmainah (2012) yang menemukan bahwa jumlah anggota komite audit tidak berpengaruh signifikan secara parsial. Keberadaan komite audit dalah perusahaan masuk bursa merupakan suatu keharusan. Sesuai dengan peraturan OJK no. 55/POJK.04/2015, komite audit setidaknya tediri dari 1 Ketua Komite Audit yang merupakan Komisaris Independen dan setidaknya 2 anggota yang terdiri dari komisaris independen dan ahli atau pihak independen lainnya dari luar perusahaan. Investor memiliki kecenderungan untuk lebih mempercayai hasil audit dari auditor eksternal dibandingkan dengan laporan dari komite audit. Terdapat kekhawatiran bahwa keberadaan komite audit tidak mencerminkan kualitas tata kelola perusahaan jika hanya dimaksudkan untuk memenuhi peraturan OJK semata. Karenanya keberadaan komite audit tidak berpengaruh terhadap pengambilan keputusan investasi oleh investor sehingga tidak mempengaruhi harga saham yang mencerminkan nilai perusahaan.

9. $\mathrm{H}_{9}$ dapat diterima. Artinya current ratio, receivable turnover, debt to equity ratio, return on assets, earning per share, persentase kepemilikan institusional, persentase dewan komisaris independen, dan keberadaan komite audit berpengaruh signifikan secara simultan terhadap nilai perusahaan. Hal ini menunjukkan bahwa secara bersama-sama current ratio, receivable turnover, debt to equity ratio, return on assets, earning per share, persentase kepemilikan institusional, persentase dewan komisaris independen, dan keberadaan komite audit menjadi factor yang menentukan keputusan investasi dari investor yang akan berpengaruh 
terhadap harga saham sebagai cermin dari nilai perusahaan.

\section{Simpulan dan Saran}

\section{Simpulan}

Simpulan pertama adalah kinerja keuangan yang diukur dengan return on assets berpengaruh signifikan secara parsial terhadap nilai perusahaan pada sub sektor industri telekomunikasi yang terdaftar di BEI. Sementara kinerja keuangan yang diukur dengan current ratio, receivable turnover, debt to equity ratio, dan earning per share tidak berpengaruh signifikan secara parsial terhadap nilai perusahaan pada sub sektor industri telekomunikasi yang terdaftar di BEI. Artinya perubahan terhadap besarnya return on assets dapat menyebabkan perubahan pada nilai perusahaan. Sedangkan perubahan terhadap besarnya current ratio, receivable turnover, debt to equity ratio, atau earning per share tidak mengakibatkan perubahan pada nilai perusahaan.

Simpulan kedua penelitian ini adalah tata kelola perusahaan yang diukur dengan persentase kepemilikan institusional dan persentase dewan komisaris independen berpengaruh signifikan secara parsial terhadap nilai perusahaan pada sub sektor industri telekomunikasi yang terdaftar di BEI. Sementara tata kelola perusahaan yang diukur dengan keberadaan komite audit tidak berpengaruh signifikan secara parsial terhadap nilai perusahaan pada sub sektor industri telekomunikasi yang terdaftar di BEI. Artinya perubahan pada persentase kepemilikan institusional dan perubahan persentase dewan komisaris independen dapat mengakibatkan perubahan pada nilai perusahaan. Sedangkan perubahan pada keberadaan komite audit tidak mengakibatkan perubahan pada nilai perusahaan.

Sementara simpulan ketiga yang diperoleh ialah kinerja keuangan dan tata kelola perusahaan secara simultan berpengaruh 114 signifikan terhadap nilai perusahaan pada sub sektor industri telekomunikasi yang terdaftar di BEI.

\section{Saran}

Berikut adalah beberapa saran yang dapat menjadi masukan bagi penelitian selanjutnya terkait nilai perusahaan: 1) Penelitian selanjutnya sebaiknya mengambil sampel dari populasi sub sektor atau sektor yang lebih besar agar dengan rentang waktu yang lebih panjang dengan tujuan memperoleh lebih banyak data sehingga hasil penelitian menjadi lebih akurat. 2) Penelitian selanjutnya diharapkan dapat menggunakan indikator kinerja keuangan maupun tata kelola perusahaan yang berbeda, terutama untuk variabelvariabel yang tidak berpengaruh signifikan. 3) Penelitian selanjutnya diharapkan juga melibatkan variabel-variabel lain yang diperkirakan dapat mempengaruhi nilai perusahaan, misalnya: kebijakan dividen, management laba, atau struktur modal.

Bagi para investor, berikut adalah beberapa saran yang dapat menjadi masukan dalam berinvestasi: 1) Dalam membuat keputusan investasi, meskipun terdapat keterbatasan informasi sebaiknya investor tidak hanya memperhatikan kinerja keuangan dalam satu periode pelaporan supaya investor menilai kondisi perusahaan serta tren perusahaan selama beberapa tahun. Investor diharapkan tidak serta merta melihat rasio keuangan yang baik sebagai sinyal positif tetapi perlu melakukan analisa fundamental yang lebih mendalam berdasarkan kondisi perusahaan dalam beberapa tahun terakhir. 2) Dalam membuat keputusan investasi, selain melakukan analisa terhadap kinerja keuangan, investor perlu memperhatikan pula tata kelola perusahaan. Dengan tata kelola yang baik dalam perusahaan tentunya menimbulkan transparasi antara manajemen dan shareholder, sehingga memberikan jaminan bahwa perusahaan tersebut mampu mengelola investasi kita dan memberikan kemakmuran bagi pemegang saham. 
Sementara bagi perusahaan, berikut adalah beberapa saran yang dapat menjadi masukan: 1) Profitabilitas masih menjadi sinyal positif bagi investor, sehingga perusahaan sebaiknya perlu meningkatkan profitabilitas melalui peningkatan kinerja perusahaan. 2) Implementasi tata kelola perusahaan yang baik dalam perusahaan menjadi perhatian yang cukup besar bagi para investor. Investor cenderung tidak lagi hanya memperhatikan kondisi finansial saja namun juga memperhatikan tata kelola perusahaan. Perusahaan sebaiknya selain meningkatkan kinerja keuangannya juga mengimplementasikan tata kelola perusahaan yang baik untuk menarik minat investor dalam berinvestasi di perusahaan tersebut.

\section{Daftar Pustaka}

Anggitasari, Niyanti dan Mutmainah, Siti. 2012. Pengaruh Kinerja Keuangan Terhadap Nilai Perusahaan Dengan Pengungkapan Corporate Social Responsibility dan Struktur Good Corporate Governance Sebagai Variabel Pemoderasi. Diponegoro Journal of Accounting, 1(2): 1-15.

Destiana, Tita. 2011. Pengaruh Rasio Keuangan, Pertumbuhan Penjualan, dan Dividen Terhadap Harga Saham. Jurnal Bisnis dan Akuntansi, 13(1): 57-66.

Dewi, Laurensia Chintia dan Nugrahanti, Yeterina Widi. 2014. Pengaruh Struktur Kepemilikan dan Dewan Komisaris Independen Terhadap Nilai Perusahaan (Studi Pada Perusahaan Industri Barang Konsumsi di BEI Tahun 2011-2013). Kinerja, 18(1): 64-80.

DP., Hj. Rina Tjandrakirana dan Monika, Meva. 2014. Pengaruh Kinerja Keuangan Terhadap Nilai Perusahaan Manufaktur yang Terdaftar di Bursa Efek Indonesia. Jurnal Manajemen dan Bisnis Sriwijaya, 12(1): 1-16.

Febrianti, Meiriska. 2012. Faktor-Faktor yang Mempengaruhi Nilai Perusahaan pada Industri Pertambangan di Bursa Efek Indonesia. Jurnal Bisnis dan Akuntansi, 14(2): 141-156.

Ghozali, Imam. 2011. Aplikasi Analisis Multivariate Dengan Program SPSS. Semarang: Badan Penerbit Universitas Diponegoro.

Ghozali, Imam. Dan Ratmono, D. 2013. Analisis Multivariate dan Ekonometrika: Teori, Konsep, dan Aplikasi dengan Eviews 8. Semarang: Badan Penerbit Universitas Diponegoro.

Pesiwarissa, Peatriex dan Simus, Nicodemus. 2014. Analisis Pengaruh Debt to Equity Ratio (DER), Retrun On Equity (ROE) dan Earning Per Share (EPS) terhadap Nilai Perusahaan. Jurnal Manajemen Akuntansi dan Studi Pembangunan, 13(2): 48-59.

Prameswari, Tania. 2016. Pengaruh Good Corporate Governance, Corporate Social Responsibility dan Profitabilitas Terhadap Nilai Perusahaan Pada Perusahaan Sektor Primer Periode 2010-2014, Tesis, Universitas Kristen Maranatha, Bandung.

Repi, Switli, Sri Murni, Decky Adare. 2016. Faktor-Faktor yang Mempengaruhi Nilai Perusahaan Subsektor Perbankan Pada BEI Dalam Menghadapi MEA. Jurnal EMBA, 4(1): 181-191.

Ross, Stephen A., Randolph W. Westerfield, Jeffrey Jaffe. 2010. Corporate Finance, $9^{\text {th }}$ Edition. New York: McGraw-Hill.

Safitri, Abied Luthfi. 2013. Pengaruh Earnings Per Share, Price Earning Ratio, Return on Assets, Debt to Equity Ratio, dan Market Value Added Terhadap Harga Saham dalam Kelompok Jakarta Islamic Index. Management Analysis Journal, 2(2): 18.

Siagian, Ferdinand, Sylvia V. Siregar, Yan Rahadian. 2013. Corporate Governance, Reporting Quality, and Firm Value: Evidence From Indonesia. 
Jurnal Akuntansi Maranathan Volume 10 Nomor 1, Mei 2018 : 98 - 116

Journal of Accounting in Emerging Economies, 3(1): 4-20.

Suhartanti, Tutut dan Asyik, Nur Fadjrih. 2015. Pengaruh Corporate Governance Terhadap Nilai Perusahaan Dengan Kinerja Keuangan Sebagai Variabel Moderating. Jurnal Ilmu dan Riset Akuntansi, 4(8): 1-15.

Welley, Morenly dan Untu, Victoria. 2015. Faktor-Faktor yang Mempengaruhi Nilai Perusahaan di Sektor Pertanian pada Bursa Efek Indonesia Tahun 2010 - 2013. Jurnal EMBA, 3(1): 972-983. 